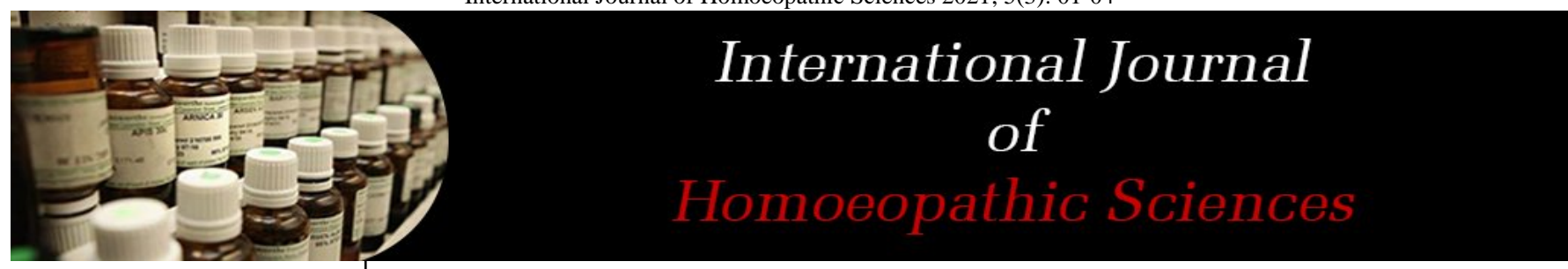

E-ISSN: 2616-4493 P-ISSN: 2616-4485 www.homoeopathicjournal.com IJHS 2021; 5(3): 01-04

Received: 02-03-202

Accepted: 06-04-2021

\section{Nisha Dhiman}

Intern, Homoeopathic Medical

College and Hospital, Sector

26, Chandigarh, India

Dr. Seema Chawla

Professor, Homoeopathic

Medical College and Hospital,

Sector 26, Chandigarh, India
Corresponding Author: Nisha Dhiman

Intern, Homoeopathic Medical

College and Hospital, Sector

26, Chandigarh, India

\section{Hypertension and role of dash diet (To reduce morbidity and mortality rates)}

\section{Nisha Dhiman and Dr. Seema Chawla}

DOI: $\underline{\text { https://doi.org/10.33545/26164485.2021.v5.i3a.393 }}$

\section{Abstract}

Hypertension means increase in pressure exerted by the blood on the arteries. It is a common condition in which the long-term force of the blood against the artery walls is high enough that it may eventually cause health problems. It usually develops over the course of several years. Usually, individual do not notice any symptoms. But even without symptoms, hypertension can cause damage to the blood vessels and organs. Thus, its prevention and early detection along with management is important. Prevention is only possible when one knows about the risk factors and causes of hypertension and management is by early detection and limiting the causes that cause hypertension.

Keywords: Yucatec maya, traditional medicine, plant use, herbalist

\section{Introduction}

Blood pressure reading is given in millimeters of mercury (mmHg). It has 2 components:

- $\quad$ Systolic pressure (upper): It measures the pressure in the arteries when the heart beats.

- Diastolic pressure (lower): It measures the pressure in the arteries when the heart rests between beats.

Normal levels of blood pressure: $120 / 80 \mathrm{mmHg}$.

\section{According to WHO}

1. An estimated 1.13 billion people worldwide have hypertension.

2. In 2015, 1 in 4 men, 1 in 5 women had hypertension.

3. Hypertension is the cause of premature death worldwide.

4. One of the global targets for non-communicable diseases is to reduce the prevalence of hypertension by 25\% (baseline 2010).

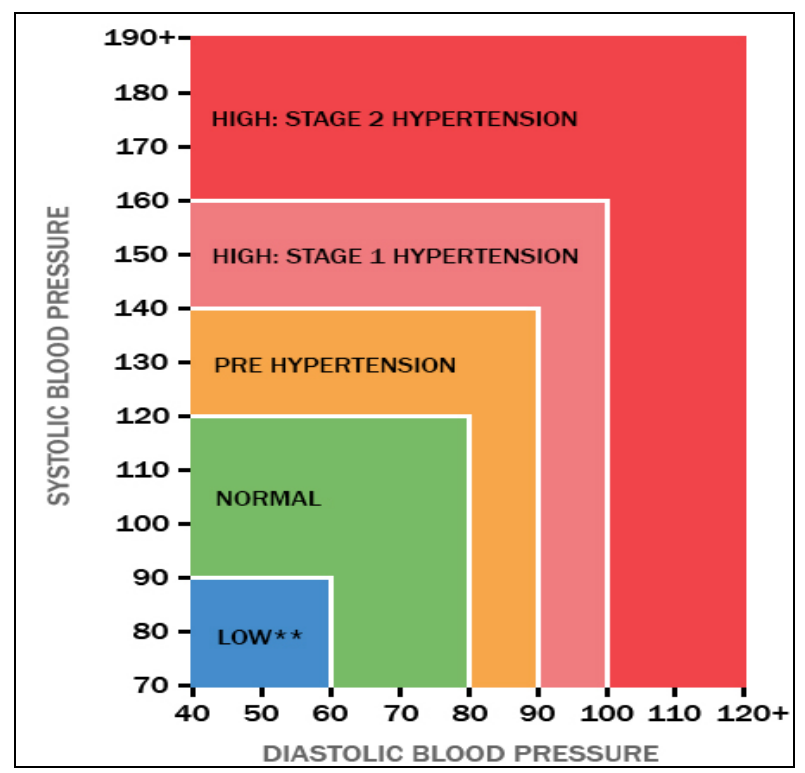

Fig 1: Shows of blood pressure 


\section{Risk factors and causes}

In India, with transformation in every little thing we have seen a radical shift in diseases from communicable to noncommunicable diseases that include Hypertension, Cancer, Cardiovascular diseases, PCOD, etc.

Most randomized controlled studies have shown that even a modest weight loss is associated with a significant reduction in blood pressure of roughly $3 \mathrm{mmHg}$ in overweight people.

\section{Individual factors}

The incidence of hypertension becomes more prevalent with age.

Genetics plays a significant role in determining who will become hypertensive. As much as $20-40 \%$ OF BP variations in the general population have been attributed to genetic factors. Along with these, lifestyle factors such as dietary patterns are implicated as one of the highest contributors to the continued high prevalence of hypertension.

Being overweight or obese also influences the blood pressure levels.

\section{Dietary factors}

- Epidemiological studies indicate a positive association between dietary salt intake, level of BP and prevalence of hypertension.

- There is an inverse relationship between intake of potassium and calcium with BP.

- Alcohol intake is found be significantly and positively related to both SBP and DBP and a change in alcohol intake was followed by a change in BP.

- INTERSALT study indicated that higher dietary protein intake has favorable influences on BP.

\section{Symptoms of hypertension and its complications}

Most of the patients do not have symptoms and are not aware of their blood pressure even if they are high. This is the reason it is called a Silent Killer disease. In cases, where it is symptomatic following are the most common symptoms: severe headaches, nosebleed, fatigue or confusion, vision problems, chest pain, difficulty breathing and sometimes irregular breathing.

Complications of later effects of Hypertension include:

- Affecting the Heart: Atherosclerotic coronary artery disease, microvascular diseases and vascular arrhythmias.

- Affecting the Brain: Infarction, hemorrhage (intracerebral or subarachnoid).

- Affecting the Eye: Hypertensive retinopathy.

- Affecting the Kidney: Chronic kidney disease and renal failure.

\section{Dash diet and its role in hypertension}

The DASH (Dietary Approaches to Stop Hypertension) diet plan was developed to lower blood pressure without medication in research sponsored by National Institutes of health. It emphasizes the right portion sizes, variety of foods and nutrients to be consumed. It encourages to reduce sodium diet \& consume a variety of food rich in nutrients that help in lowering blood pressure, such as potassium, calcium and magnesium. It focuses on fruits, vegetables, whole grains and lean meat.

The diet was created after researcher's noticed that high blood pressure was much less common in people who followed a plant based diet, such as vegans and vegetarians. Scientists believe that one of the main reasons people with high blood pressure can benefit from this diet is because it reduces salt intake. (Recommended intake $-3 / 4^{\text {th }}$ to $1 \mathrm{tbs}$ ).

Let's have a look on some of the ingredients included in DASH diet:

1. Dietary Fats: Effects of dietary fats on blood pressure have also become more evident through observational and experimental research. It is observed through experiments that voltage-gated $\mathrm{Ca}^{2+}$ current density is significantly increased in hypertension and can be affected by free fatty acids (FAs).

It includes: Butter, Beef or Pork fat, Margarine, Fried food and processed snacks etc.

2. Sodium: It has been studied extensively in animal experimental models, in epidemiological studies, controlled clinical trials and in population studies that salt or sodium intake has been directly correlated with mean blood pressure levels and prevalence of hypertension in many populations. (INTERSALT Study).

3. Potassium: A protective effect of potassium on blood pressure was suggested by clinical studies reporting that sever short term potassium restriction includes salt sensitivity in normotensive humans, as well as the blood pressure lowering effect of potassium supplements to the diet in hypertensive subjects.

4. Nuts: There is an inverse dose relation between the frequency of nuts and blood pressure values. But these should be consumed as per the desired energy levels.

5. Protein: Studies like observational and RCT's have demonstrated that protein supplementation or the replacement of protein for fat or carbohydrate results in lower blood pressure.

6. Magnesium: Magnesium as a potential dietary antihypertensive has been investigated in numerous studies. When compared to persons using regular table salt as a seasoning, ingestion of a "Smart Salt" composed of $50 \%$ sodium chloride, $25 \%$ potassium chloride and $25 \%$ magnesium ammonium potassium chloride, led to significantly lower blood pressure over 8 weeks.

7. Others include: Dietary fiber should be increased. Alcohol should be reduced. 


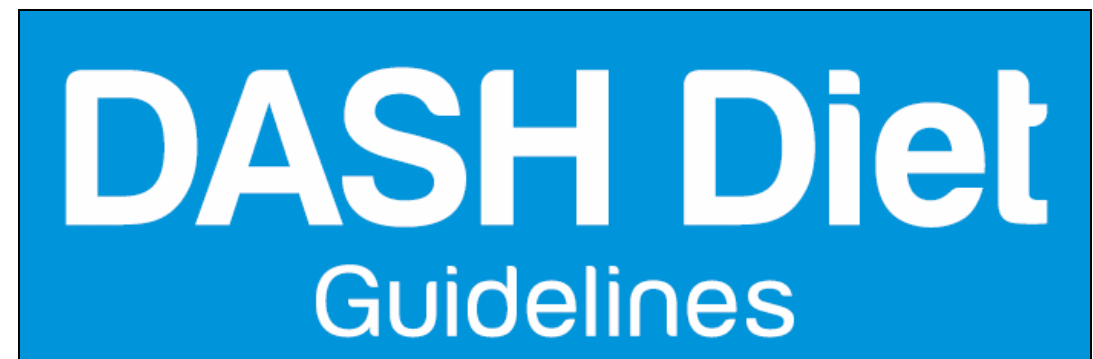

\begin{tabular}{|c|c|c|c|}
\hline \multirow{2}{*}{\begin{tabular}{|l} 
Type \\
Sodium
\end{tabular}} & \multicolumn{2}{|l|}{ Amount } & \multirow{2}{*}{$\begin{array}{l}\text { Comments } \\
\begin{array}{l}\text { The DASH Diet strongly recommends } \\
\text { reducing sodium consumption. }\end{array}\end{array}$} \\
\hline & $\begin{array}{c}\text { Standard } \\
\leq 2,300 \mathrm{mg} \\
\text { per day }\end{array}$ & $\begin{array}{l}\text { Lower Sodium } \\
\leq 1,500 \mathrm{mg} \\
\text { per day }\end{array}$ & \\
\hline Alcohol & \begin{tabular}{|c|} 
Men \\
$\leq 2$ drinks \\
per day
\end{tabular} & $\begin{array}{l}\text { Women } \\
\leq 1 \text { drink } \\
\text { per day }\end{array}$ & $\begin{array}{l}\text { Too much alcohol isn't healthy for blood } \\
\text { pressure. }\end{array}$ \\
\hline Sweets & \multicolumn{2}{|c|}{$\begin{array}{l}5 \text { servings or less } \\
\text { per week }\end{array}$} & $\begin{array}{l}\text { The DASH Diet recommends fat-free or } \\
\text { low-fat treats and also suggests using } \\
\text { artificial sweeteners when you're craving } \\
\text { sweets. }\end{array}$ \\
\hline Fats and oils & \multicolumn{2}{|c|}{$\begin{array}{l}\text { 2-3 servings } \\
\text { per day }\end{array}$} & $\begin{array}{l}\text { Both saturated fats and trans fats are } \\
\text { especially discouraged on the DASH Diet. }\end{array}$ \\
\hline $\begin{array}{l}\text { Nuts, seeds, } \\
\text { and legumes }\end{array}$ & \multicolumn{2}{|c|}{$\begin{array}{l}\text { 4-5 servings } \\
\text { per week }\end{array}$} & $\begin{array}{l}\text { Because these foods are higher in calories, } \\
\text { they're recommended only a few times a } \\
\text { week. Yet they are also quality sources of } \\
\text { magnesium, potassium, and protein as } \\
\text { well as fiber and phytochemicals. }\end{array}$ \\
\hline $\begin{array}{l}\text { Lean meat, } \\
\text { poultry, and } \\
\text { fish }\end{array}$ & \multicolumn{2}{|c|}{$\begin{array}{l}6 \text { servings or less } \\
\text { per week }\end{array}$} & $\begin{array}{l}\text { Meat is recommended because it provides } \\
\text { protein, B vitamins, iron, and zinc. } \\
\text { However, the DASH diet recommends } \\
\text { cutting back on meat portion sizes to } \\
\text { make way for more vegetables. }\end{array}$ \\
\hline $\begin{array}{l}\text { Dairy (milk, } \\
\text { yogurt, and } \\
\text { cheese) }\end{array}$ & \multicolumn{2}{|c|}{$\begin{array}{l}\text { 2-3 servings } \\
\text { per day }\end{array}$} & $\begin{array}{l}\text { Dairy provides ample amounts of calcium, } \\
\text { vitamin D, as well as protein. Low-fat and } \\
\text { fat-free versions are more highly } \\
\text { recommended. Go light on cheeses } \\
\text { because they tend to be higher in sodium. }\end{array}$ \\
\hline Fruits & \multicolumn{2}{|c|}{$\begin{array}{l}\text { 4-5 servings } \\
\text { per day }\end{array}$} & $\begin{array}{l}\text { Because they provide fiber, potassium, } \\
\text { and magnesium, fruits are considered a } \\
\text { healthy part of any meal or snack. }\end{array}$ \\
\hline Vegetables & \multicolumn{2}{|c|}{$\begin{array}{l}\text { 4-5 servings } \\
\text { per day }\end{array}$} & $\begin{array}{l}\text { High in potassium and magnesium along } \\
\text { with fiber, vegetables aren't just a side } \\
\text { dish. }\end{array}$ \\
\hline$\overline{G r a i n s}$ & \multicolumn{2}{|c|}{$\begin{array}{l}\text { 6-8 servings } \\
\text { per day }\end{array}$} & $\begin{array}{l}\text { With a focus on whole grains for their } \\
\text { added fiber. }\end{array}$ \\
\hline
\end{tabular}

Fig 2: Shows in DASH Diet guidelines

\section{References}

1. Nwankwo T, Yoon SS, Burt V, Gu Q. Hypertension among adults in the United States: National Health and Nutrition Examination Survey, 2011-2012. NCHS Data Brief 2013;(133):1-8.

2. Booth JN, Li J, Zhang L, Chen L, Muntner P, Egan B. Trends in Prehypertension and Hypertension Risk Factors in US Adults: 1999-2012. Hypertension
2017;70(2):275-284.

doi:10.1161/HYPERTENSIONAHA.116.09004

3. Stamler J, Chan Q, Daviglus ML, et al. Relation of Dietary Sodium (Salt) to Blood Pressure and Its Possible Modulation by Other Dietary Factors: The INTERMAP Study. Hypertension 2018;71(4):631-637. doi:10.1161/HYPERTENSIONAHA.117.09928

4. Law MR. Epidemiological evidence on salt and blood 
pressure Am J Hypertens 1997;10:42S-45S.

5. Mizushima S, Cappuccio FP, Nichols R, Elliott P. Dietary magnesium intake and blood pressure: a qualitative overview of the observational studies. J Hum Hypertens 1998;12:447-453.

6. Rosanoff A. Magnesium supplements may enhance the effect of antihypertensive medications in stage 1 hypertensive subjects. Magnes Res 2010;23:27-40. doi: 10.1684/mrh.2010.0198

7. By Adam Chapman Published: 10:41, Wed, Aug 12, 2020.

8. Teunissen-Beekman KF, van Baak MA. The role of dietary protein in blood pressure regulation. Curr Opin Lipidol 2013;24:65-70.

9. Department of Physiological Medicine, St. George\&\#39;s Hospital Medical School, London, UK. Journal of Hypertension 1991;9(5):465-473.

10. Institute of Medicine (IOM) Food and Nutrition Board. Dietary Reference Intakes for Calcium, Phosphorus, Magnesium, Vitamin D, and Fluoride. Washington, DC: National Academy Press 1997.

11. Burke V, Beilin LJ Sciarrone S. Vegetarian diets, protein and fiber-Part 3, Pathogenesis, in Swales JD (eds) extbook of Hypertension. London, Blackwell Scientific Publications 1994;3l:619-632.

12. Steinberg D, et al. The DASH diet, 20 years on 2017.

13. Paula TP, Viana LV, Neto AT, Leitao CB, Gross JL, Azevedo MJ. Effects of the DASH diet and walking on blood pressure in patients with type 2 diabetes and uncontrolled hypertension: a randomized controlled trial. J Clin Hypertens 2015;17:895-901.

14. De Paula TP, Steemburgo T, de Almeida JC, Dall'Alba V, Gross JL, de Azevedo MJ. The role of Dietary Approaches to Stop Hypertension (DASH) diet food groups in blood pressure in type 2 diabetes. $\mathrm{Br} \mathrm{J}$ Nutr 2012;108:155-162.

15. National Heart, Lung, and Blood Institute Your Guide to Lowering Your Blood Pressure with DASH. NIH Publication no. 06-4082. Bethesda, MD: NIH, National Heart, Lung, and Blood Institute 2006.

16. Appel L, Moore T, Obarzanek E, et al. A clinical trial of the effects of dietary patterns on blood pressure. $\mathrm{N}$ Engl J Med 1997;336;1117-1124. 